\title{
Outgroup Resident's Attitude towards The Existence of Special Islamic Housing
}

\author{
Hendro Prabowo \\ Faculty of Psychology \\ Gunadarma University, \\ Depok, Indonesia \\ ndrahu@yahoo.com
}

\author{
Mahargyantari P. \\ Dewi \\ Faculty of Psychology \\ Gunadarma University, \\ Depok, Indonesia \\ mp_dewi@yahoo.co.id
}

\author{
Henny Regina Salve \\ Faculty of Psychology \\ Gunadarma University, \\ Depok, Indonesia \\ alve_7@yahoo.com \\ (Corresponding author)
}

\author{
Afmi Fuad \\ Faculty of Psychology \\ Gunadarma University, \\ Depok, Indonesia \\ afmifuad@gmail.com
}

\begin{abstract}
Gated community is a gated residential area its mean as term with a negative connotation related to social segregation. Today there has also been a growing upper class housing that is devoted to Muslims in Jakarta. One of them is Light Islamic Townhouse in East Jakarta. This case study examines the attitude of the out-group resident to the housing, where the out-group resident is the same neighborhood with the resident of the housing (living in the same Rukun Tetangga). With interviewed to 16 participants and did participant observation, the results show that middle class from the outgroup resident consider the existence of the housing as closed, unwilling to blend, and exclusive. While the lower class from the out-group resident considered the existence of the housing to be positive and profitable because of cross subsidies. Practical and theoretical implications are discussed.
\end{abstract}

Keywords: attitude, out-group, gated community.

Received 21 May 2019/Accepted 24 July 2019 CJEHCP All rights reserved

\section{Introduction}

James and Gail (1997) say that, a gated community is a residential area that has limited access which is usually privatized by public space. As a developer also determines security limits, such as walls or fences, and controls the entrance that aims to prevent the entry of outside residents. These community developers include new developers. Old housing areas are usually equipped with gates and fences. The residents of the gated community can be found and live downtown to the countryside and from the richest neighborhoods to the poorest. Based on an 
explanation from the two security officers, their gate was guarded by two officers at the post I guard house managed 24 hours a day who went around and then rolled back to the gate made of iron and using simple electronics. Post/guard house is usually built on two lines, which is one lane for guests and visitors and the second is for residents, which can open the gate with electronic cards, codes, or remote control devices. Some communities which has 24-hour security always require whole car must pass the guard pass, and show stickers as identification for resident cars. In addition, there is also a video camera for recording license plate numbers and also detecting the faces of all people who pass by. Meanwhile, the entrance without guards uses an intercom system, and some use video monitors which functioned for residents to be able to monitor visitors.

Gated community is a housing area with access restrictions where the public space in it is made a private area for its residents. This community determines itself as to what the perimeter limit is, for example in the form of a wall or fence and controls the gate to prevent the entry of outside residents. This community includes those built by developers and equipped with special gates with high fences, and can be found from the downtown to the countryside or in the rich neighborhood to the poor. This guard post is usually built two lanes, one lane for guests or visitors and the second lane for residents, it could be by gates that use electronic cards, codes, or remote control devices. Some communities with 24-hour security require all cars to pass by guards and show identification stickers for residents' cars. Others use video cameras to record car number plates and faces for all who pass.

Grant and Mittelsteadt (2004) define a gated community is a housing development on private roads closed to general traffic by a gate across the primary access. The developments may be surrounded by fences, walls, or other natural barriers that further limit public access. Similar to James and Gail, Grant and Mittelsteadt (2004) define gated community as housing that has private roads that are closed to public traffic and are limited by a gate that crosses primary access. This housing also builds fences, walls or other natural barriers to limit public access. Atkinson and Blandy (2005) add that, this community can include various services such as shops 
or recreational facilities. This building is usually also governed by a legal and social framework that forms a legal condition that must be fulfilled by residents. In addition, this gated community can be new housing and an older housing area (Blakely, 2007).

\section{Types of gated community}

There are three types of gated communities according to Lakely and Snyder (1997) namely lifestyle communities, prestige communities, and security zone communities. The core of the lifestyle community focuses on recreational activities with recreational facilities, public facilities, and shared services. Places that are a part of lifestyle, including resorts in villages, golf communities, or new cities on the outskirts of the city. Developers have a target to get residents who have a number of similarities such as the characteristics of an identity, who want security guarantees, and expect to have a way of life that suits their neighbors. The Developers try to manifest a feeling of togetherness for residents with shared interests and activities. Lifestyle characteristics in a community are often shown on a golf course or country club.

The function of the prestige community is as a symbol of wealth and maintaining the impression of status for its inhabitants. This gate prevents a group of people from seeing how the rich lived. They highlight a number of interesting settings, but they do not accompany public facilities or facilities. Security zone communities characterize by closing public roads for non-residents. It usually carried out by residents in the security area. There is fear from outsiders who can interfere with or threaten the environment. Although the developer has placed security at the gate position in the community, but it looks like the security zone came from the occupants themselves as the entrance and created a barrier.

Weighing the burden of the population due to the many urban problems, they can ask local governments to close roads or limit their environment to prevent outsiders from accessing. To prevent crime, maintain property values and traffic restrictions, walls and gates are built. Generally, the streets are seen by citizens as a final effort to get back the community they have. This effort has an impact, where the pattern of movements, especially traffic, was changed to 
accommodate road closures. As a proof, the area of rich people most successfully achieved their community goals, even communities from of all income levels have tried to use gates to gated community.

Negative term of gated community

Roitman (2010) describes that the existence of individual desires, interests, perspectives and opportunities triggers subjectivity from the expansion of the gated community. The causes of subjectivity include: finding social homogeneity, the desire to have a feeling of togetherness in a community, having a high fear of experiencing crime, seeking a better lifestyle, and hoping to have a higher social status and be able to show social differences in particular social groups. Edgü \& Cimșit (20II) found that living in a gated community usually resides in smaller and more limited residential units, residents provide a number of facilities for social adaptation, and increasing social relations, so that have an impact on satisfaction for the neighborhood in that community.

Roitman (2010) explains the existence of subjective causes including an increase in fear of crime, a matter of improving lifestyle, a sense of belongingness in a community, social homogenies, social status aspirations, and social differentiation in certain social groups. Furthermore, Edgü \& Cimit (20II) added that security would be maintained if living in this environment because of the limited housing units, facilitated by the social adaptation of its inhabitants, and the consequence was occupant satisfaction.

According to James and Gail (1997), regulation of restrictions is a form of political action. This boundaries determines the membership if someone does have to be in a deep position and someone else is in an outside position. This boundaries also builds and describes the place as a facility of activities and life goals for political, economic and social activities. So, the boundary in gated community can contribute to social segregation (Landman, 2000; Manzi\& Bowers, 2005; Le Goix, 2005; Roitman, 2010), lack of opportunities for the poor to live in the city (Landman, 
2000), there is a trigger for social tension between inside and outside, and the breakdown of 'differentiation' makes it dangerous (Roitman, 2010).

Gate community in Indonesia

According to Grant \& Mittelsteadt (2004), even the most extensively documented in the United States, well-preserved community security has appear in many countries, including Australia, rgentina, Australia Bahamas, Brazil, Costa Rica, Indonesia, Latvia, Portugal, South Africa, Venezuela, Britain and Canada. In Indonesia, gated community are developed in Jakarta (Leisch, 2002), Bali (Hishiyama, 2010), Yogyakarta (Hartanto, 2016), Medan (Aulia, \&Marpaung, 2017), and Depok (Hawley, 2017b).

Initially, gated community in Indonesia was developed at Mentengarea in Central Jakarta, which was originally inhabited by Dutch colonial rulers and later by the Chinese upper classes and their assistants from former president Soeharto. And then, the development of Lippo Karawaci began in 1992, and Bumi Serpong Damai in 1989 (Leisch, 2002). In recent years, fear has come to some Jakarta residents about the rise of Islamic conservatism. The only recent event was a mass protest on the streets of Jakarta which was commandeered by hardline Islamic groups who opposed the Governor of Christianity (Hawley, 2017a).This phenomenon is thought to affect the development of the gated community specifically for Muslims. Hawley (2017b) conducted an interview with one of the residents in a gated Muslim housing estate. He (the occupants) feels safe in the community, when Christians or other religions are not accepted. "For me as a Muslim, I am comfortable living here ..." It's easier to adapt in here because we have the same beliefs, how should I say it ? A homogeneous community makes me feel comfortable. "

Today there are many housing estates known as Islamic housing or sharia housing, both lowcost housing and luxury housing, all of which are Sharia systems without usury, banks, seizures, and fines. Locations in Jakarta, Bogor, Depok, Tangerang, and Bekasi (Jabodetabek), as well as Bandung, Purwakarta, Cikampek, Sukabumi, Garut, and Ciamis (Indonesian Islamic Housing, 2019). However, the existence of this type of housing cannot be determined whether it is a 
gated community or not. This research was conducted in the East Jakarta area towards one of the upper class housing that is dedicated to Muslims in Jakarta, called Light Islamic Townhouse. The previous study about gated community and attitude toward it, especially Islamichousing or sharia housing is limited. Currently, there is no study that conducted regarding gated community, therefore the current study contribute to answer it. The proposed research question is what is the out-group attitude of Light Islamic Townhouse to the existence of this special Islamic housing?

\section{Method}

The focus of this study was a four-week interview and observation at Light Islamic Townhouse. This Townhouse is located in the area of Rukun Tetangga (RT) 04 Rukun Wilayah 08, Kelurahan Kelapa Dua Wetan, Ciracas Sub District, East Jakarta. Based on Blakely and Snyder (1997), the town house tends to a security zone communities. The RT 04 area has three types of settlements, namely: two townhouses for upper class residents, housing for middle class residents and kampong for lower class residents.

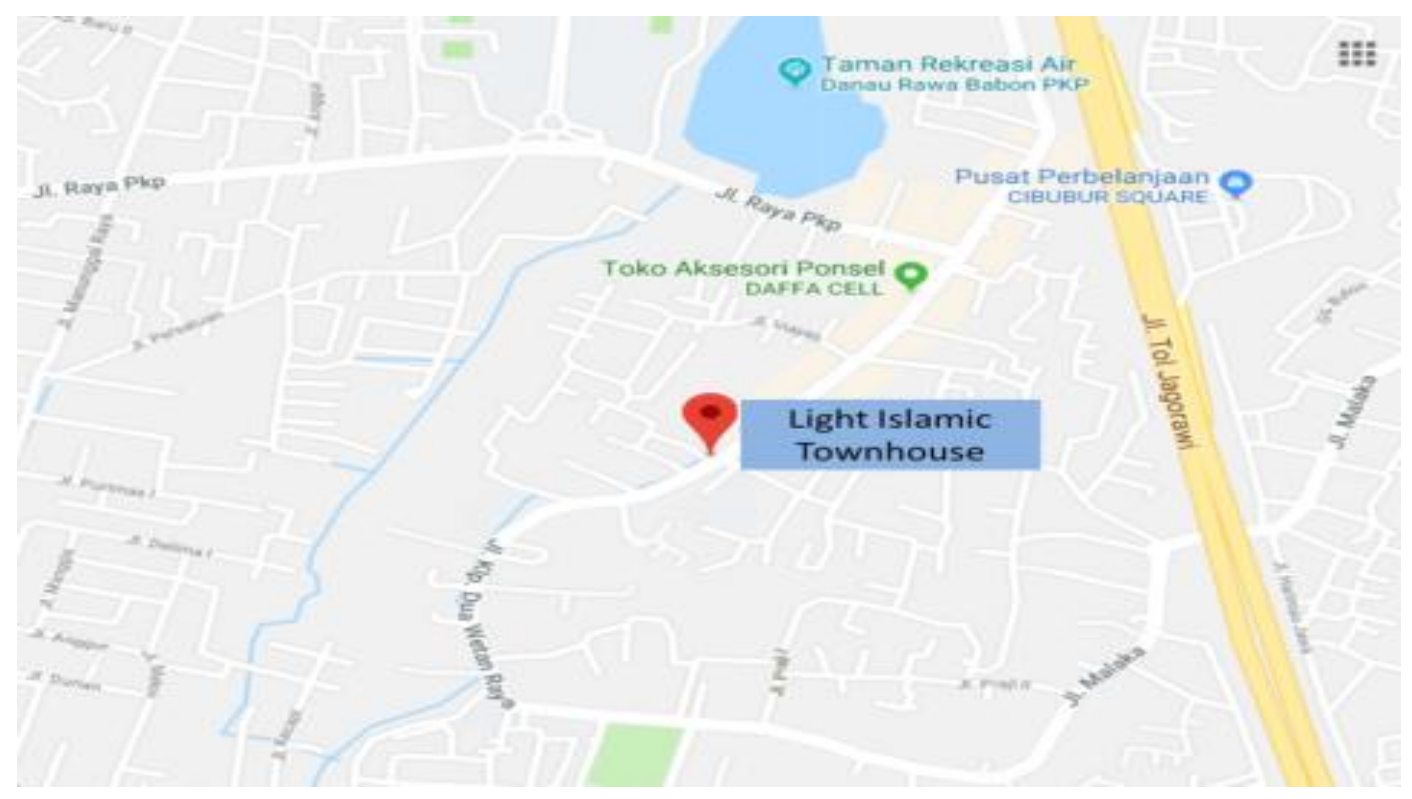

Figure I. Map of the townhouse 
Participants were 16 people from outgroups or residents outside the Light Islamic Townhouse (LIT), consists of 3 men and 13 women. These participants consist of residents who live in kampong (low class) and residents who live in housing (middle class). The researcher conducted interviews and observations of the research participants, and document of the LIT's resident activity. So, the data collection matrix was presented in table I. The two questions raised in this study are: What do you know about LIT? What do you think about LIT?

Table I

The sources of Data collection matrix / Variety of information

Source of Information/Information Observations Interviews Document

Residents who live in kampong $\quad$ Yes $\quad$ Yes

Residents who live in housing

LIT's resident activity

Yes

The data was analyzed manually through categorical aggregations (Creswell, 1998). The information and observation from each interview transcript were numbered in paragraphs, then grouped into some themes. The researcher subsequently grouped them into several categories based on these themes. Several categories are obtained from resident who live in kampong and resident who live in housing. In order to find several themes, these categories were arranged chronologically, which are exclusion, inclusion and positive perception. Finally, these categories and themes were written in a narrative including quotations and documentation results from participants.

\section{Result}

\section{Exclusion}

The theme of exclusion was obtained from participants living in housing or those from the middle class. LTI is a special Islamic housing, where residents do not want to join with residents from the same neighborhood (RT 04). The townhouse residents are upper class people who 
are busy and rarely at home, because only Sundays they are at home. They seemed closed because the houses were blocked by walls, so they did not know each other with people outside their housing. Three participants also claimed to not know of the existence of this townhouse. The occupants at LIT are also not careless in accepting guests, because they have to report to security. In addition, according to one participant, "Mothers cannot receive guests if they are not accompanied by their husbands".

The participants generally also did not know what activities were carried out by the LIT residents, except that they had their own mosque, the mothers used the Syar'i veil and if the celebration of Independence Day they made their own program which was separated from other RT 04 residents. They also do not know how many units of the house and the number of residents. One participant hopes that the residents of LIT can blend with other residents. "It's okay, but if possible the neighbors will socialize, blend with other citizens."

Activities carried out by residents of LIT are religious activities specifically for residents of LIT. The religious activities are in the form of I'tikaf, bi-weekly studies, hospitality (silaturahmi), and family gatherings.

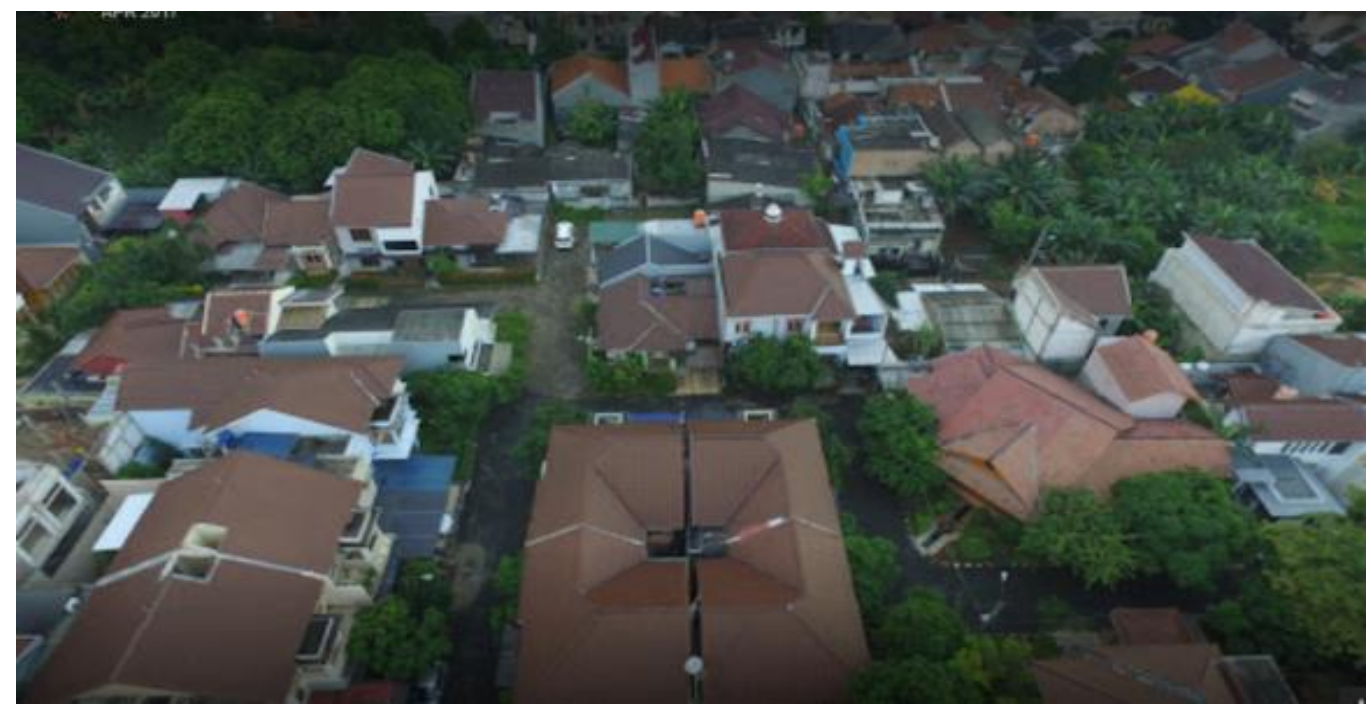

Figure 2. Perspective view of LIT 
Inclusion

The existence of LIT is also inclusive in relation to religious activities. When performing fasting and Eid al-Adha celebrations, LIT residents participate directly and indirectly in the kampong. One participant argued, "When religious celebrations in the fasting month or Eid al-Adha, they are involved in both their homes and kampong." While other participants argued, "For Eid al-Adha, they gave a goat to a mosque on RT 04."

For residents who live in kampong, the existence of LIT benefits them. They generally become gardeners, security, and maid servants, resulting in cross subsidies. It seems that they receive more than they should get, because there is additional zakat and ibadahUmrah if they are lucky. One participant said: "I always receive zakat every year from housing owners. Their gardeners can also get Umrah for free."

Positive perception

Not all participants from housing have a negative perception of LIT. On the contrary, there are those who perceive as things in terms of comfort, neatness, cleanliness, beauty and security. This can also be a dream for them. One participant said: "As far as I know, LIT housing is comfortable, regularly organized Islamic housing ... and good. In my opinion, ... if there were funds for housing like that, LIT was my dream." Another participant said that LIT was. "Beautiful, cool, safe environment is also clean ...”.

\section{Discussion}

The existence of LIT as an Islamic gated community was also apparently perceived as a safe environment for outgroups. This is also thought to be perceived by the resident. This supports the opinion of Roitman (2010) that subjective causes to live in gated communities the desire to have a feeling of togetherness in a community, having a high fear of experiencing crime, seeking a better lifestyle, and to have a social homogeneity. However, with the exclusion and inclusion of residents to their outgroup, it is evident that this gated community does not necessarily 
result in social segregation (Landman, 2000; Manzi \& Bowers, 2005; Le Goix, 2005; Roitman, 2010) and lack of opportunities for the poor to live in the city (Landman, 2000). The upper class community that runs Islam well is thought to be a factor that affects the inclusiveness of residents of the townhouse with other residents. This is indicated by the positive relationship between LIT residents and their workers who live in the village (Lower class). This finding support Miller \& Brewer (1986), and Dovidio, Gaertner, \& Kawakami (2003) that positive intergroup interaction, in this case a cross subsidies and cooperation between lower and upper class, will be effective in reducing prejudice. Otherwise, Conversely, most people from the middle class who live in housing assume that the existence of LIT community is a form of exclusivity. This is due to the lack of interaction between resident LITs and housing residents. In addition, the Resident LIT also has its own activities that do not involve residential residents. Hence, the lack of communication and cooperation actually raises some prejudice. Only a few participants from housing residents have a positive attitude towards the LIT community, related to their socio-economic and religious aspirations. So, it can be concluded that in one neighbor, LIT community is not only exclusive for housing residents but also inclusive for residents of the village and few residents of housing (Figure 3).

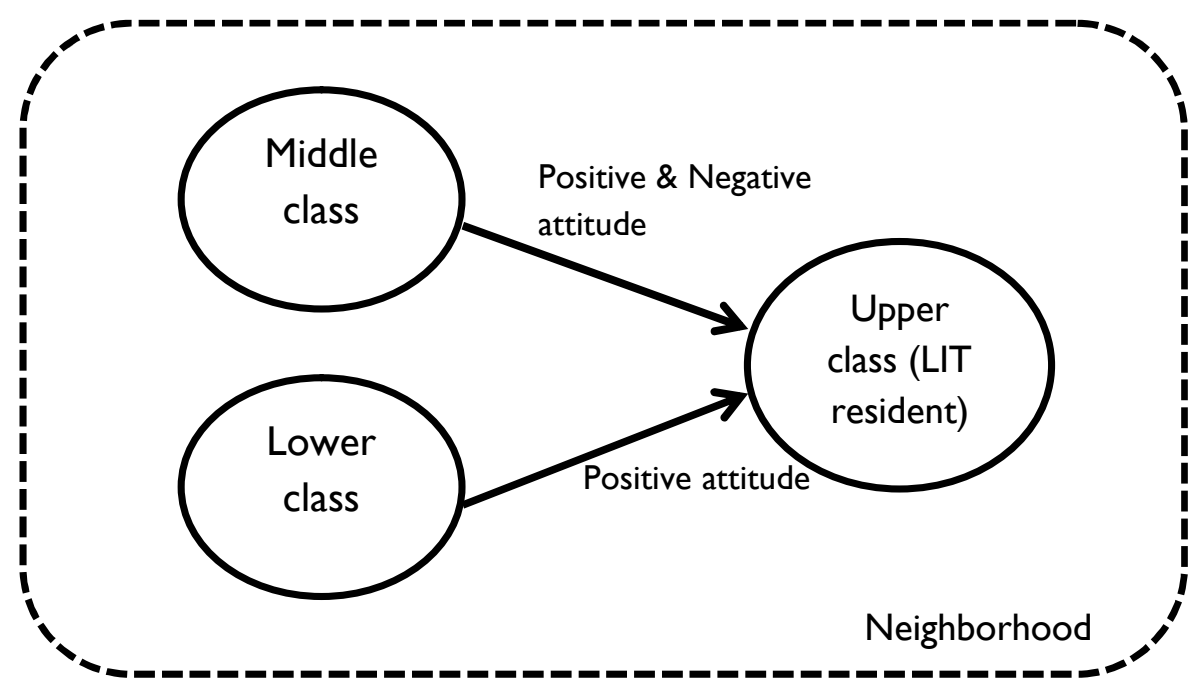

Figure 3. Attitude from outgroup to LIT resident 
Dasgupta (2004) also found that that people's implicit attitudes about ingroups relative to outgroups are influenced by two different forces: first, the tendency to prefer groups associated with the self as a confirmation of their positive self-esteem. Secondly, the tendency to prefer groups valued by the mainstream culture as a confirmation of the sociopolitical order in society. As a result of these opposing tendencies, members of disadvantaged social groups show more variable implicit attitudes toward their ingroup and, on average, show less ingroup favoritism, and sometimes even outgroup favoritism. In this study, some middle class perceives the upper class positively related to their religious aspirations to increase self-esteem; and socio-economic aspirations to improve their status.

The social identity theory focuses on how group membership influences one's self-concept and one's relationship with in-group members and outside-group members (Tajfel \& Turner, 1986). According to Hogg and Abram (1988) in a society, it consists of social categories which are classifications of people, including based on social class. Within each of this social categories is inherent a strength, status and dignity which ultimately gives rise to a distinctive social structure in society, namely a structure that determines the strength and status of relationships between individuals and between groups. Basically every individual wants to have a positive social identity. This is an effort to get recognition from other parties and social equality.

In fact, Laker (in Taylor \& Moghaddam, 1994) found that in a situation where individuals or groups feel their identity as a member of a group is less valuable, there will be a phenomenon of misidentification, an effort to identify other identities/groups that are considered better. This can be found in some kampong and housing residents who tend to underestimate their own groups and prefer to identify residents of the townhouse.

In view of social identity theory, the desire to have a positive social identity is seen as an important psychological force behind individual actions in every social interaction. This takes place through a social comparison process that is seen as a way to determine the position and status of social identity (Taylor \& Moghaddam, 1994). The process of social comparison is a 
series of comparisons with other people/groups that subjectively help individuals make special judgments about their social identity compared to other social identities (Hogg \& Abram, 1988).

Besides that according to Festinger (1954) about the process of social comparison that motivation is non-social but satisfaction becomes social when people cannot evaluate their opinions and abilities, in this situation, people evaluate their opinions and abilities by comparing themselves with people who are similar to them on the relevant dimensions.

\section{Conclusion}

The existence of LIT is considered as a safe environment for its residents, giving rise to a feeling of subjectivity among its residents, but this subjectivity does not always result in a positive attitude towards other residents in the neighborhood. Middle class residents consider the existence of LIT as a form of exclusivism because of the lack of social interaction. Meanwhile, for the lower class the existence of LIT is actually a form of inclusivism, because of the cross subsidy. Positive intergroup interaction between lower class (as a worker) and upper class (LIT resident) will be effective in reducing prejudice and overcoming positive attitude. Meanwhile, the lack of communication and cooperation between the middle class (housing resident) and upper class (LIT resident) can generate prejudice or negative attitude.

\section{Recommendation}

This study provides recommendations for developers who will build upper class housing. They should pay attention to the local resident from the lower classes and develop a designs that increase interactions with local residents who also needed by gated community residents.For LIT, the way is to open a barrier that limits the upper class housing with the village where the lower class live and housing where the middle class live. LIT is located on the main road (Kelapa Dua Wetan street), while kampong and housing are located behind LIT and must pass through a circular road (Renewal street). By opening the north-west wall, the limiting access becomes 
open. Workers from kampong no longer have to turn to LIT and housing residents can also interact directly with LIT residents. The existence of a mosque can also be used as a unifying space for Islamic holiday activities. While empty land can be used as a social space that can unite the three groups (Figure 4).

This research has a weakness in not involving the participant of the LIT resident, so this can be recommended to future researchers. Some things that can be studied include resident LIT as outgroup, prejudice, and inclusivism.

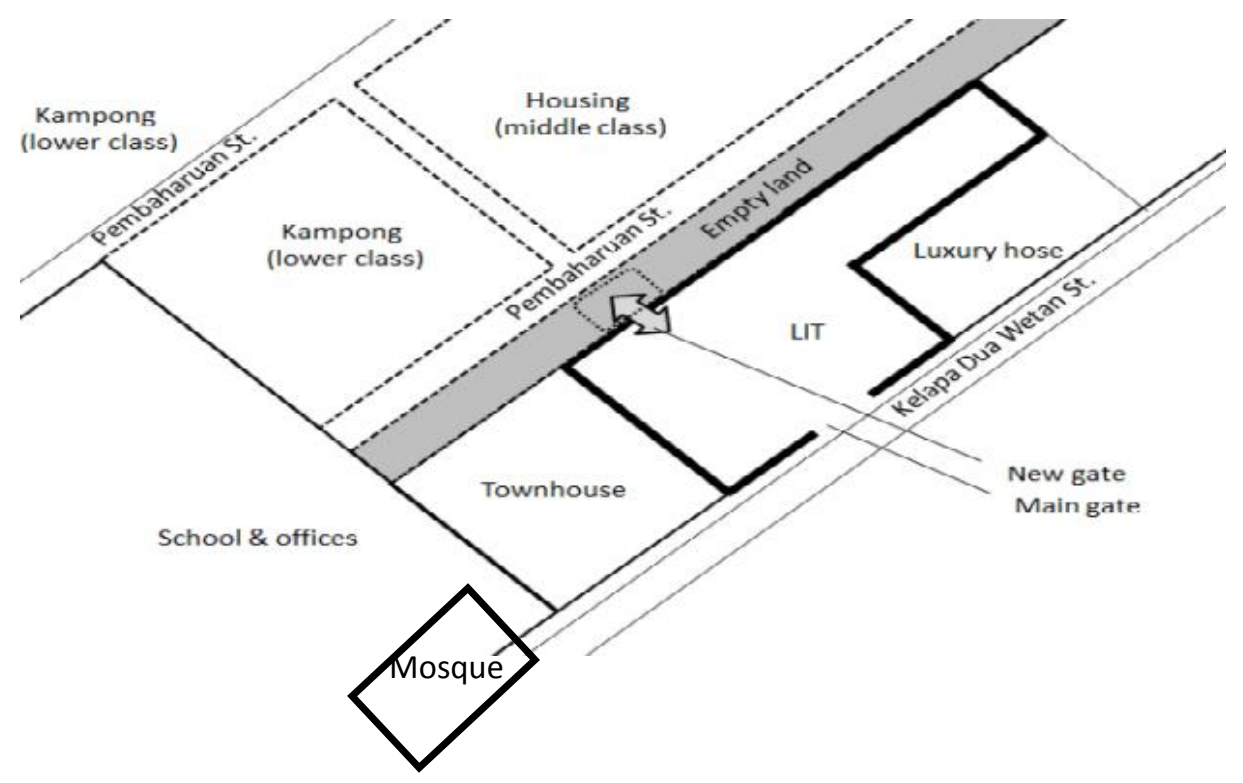

Figure 4. Recomendation for new gate to connect to the housing and the kampong 


\section{References}

Atkinson, R., \& Blandy, S. (2005). Introduction: International perspectives on the new enclavism and the rise of gated communities. Housing studies, 20(2), 177-186.

Atkinson, R., \& Flint, J. (2004). Fortress UK? Gated communities, the spatial revolt of the elites and time-space trajectories of segregation. Housing studies, 19(6), 875-892.

Aulia, D. N., \&Marpaung, B. O. (2017). Transformation of gated community in the last three decades in Medan City, Indonesia. IPTEK Journal of Proceedings Series, 3(3).

Bagaeen, S., \& Uduku, O. (2010). Gated communities. Social sustainability in contemporary and historical gated developments. London: Earthscan.

Blakely, E. (2007). Gated communities for a frayed and afraid world. Housing Policy Debate 18(3), $475-480$.

Blakely, E.J., \& Snyder, M.G. (1997).Fortress America: Gated communities in the United States. Washington: The Brookings Institution.

Creswell, J. W. (1998). Qualitative inquiry and research design: Choosing among five traditions. Thousand Oaks, CA: Sage.

Dasgupta, N. (2004). Implicit ingroup favoritism, outgroup favoritism, and their behavioral manifestations. Social Justice Research, I7(2), I43-169.

Dovidio, J. F., Gaertner, S. L., \& Kawakami, K. (2003). Intergroup contact: The past, present, and the future. Group Processes \& Intergroup Relations, 6(I), 5-2I.

Edgü, E., \& Cimșit, F. (20I I). Island living as a gated community: Place attachment in an isolated environment. A| Z ITU Journal of the Faculty of Architecture, 8(2), I56-I77.

Forrest, R., \& Kearns, A. (200I).Social cohesion, social capital and the neighbourhood. Urban studies, 38(I2), 2I25-2|43.

Grant, J., \& Mittelsteadt, L. (2004).Types of gated communities. Environment and Planning B: Planning and Design, 3 I(6), 9/3-930.

Hartanto, T. (2016). Gated community: Studi kasus perumahan Casa Grande di Yogyakarta. Teknik Sipil dan Arsitektur, 18(22), I-9.

Hawley, S. (2017a). Muslim-only gated housing booming in Indonesia http://www.abc.net.au/am/content/2016/s4706775.htm

Hawley, S. (2017b). Diversity concerns as gated Muslim communities in popularity in Indonesia. https://www.abc.net.au/news/2017-07-24/gated-muslim-communities-rising-popularity-inindonesia/8736246. 
Hishiyama, K. (2010). Uneasy society in Indonesia: With special attention to the gated community and CCTV in Bali. Procedia-Social and Behavioral Sciences, 2(I), I4-23.

Hogg, M.A.,\& Abram, D.(1988). Social identification: A social psychology of intergroup relation and group processes. London: Routledge.

Landman, K. (2000). Gated communities and urban sustainability: taking a closer look at the future.

Le Goix, R. (2005). Gated communities: Sprawl and social segregation in Southern California. Housing studies, 20(2), 323-343.

Leisch, H. (2002). Gated communities in Indonesia. Cities, I9(5), 34I-350.

Manzi, T., \& Smith-Bowers, B. (2005). Gated communities as club goods: Segregation or social cohesion? Housing Studies, 20(2), 345-359.

Miller, N., \& Brewer, M. B. (1986). Categorization effects on ingroup and outgroup perception. In J. F. Dovidio \& S. L. Gaertner (Eds.). Prejudice, discrimination, and racism (pp. 209-230). San Diego, CA, US: Academic Press.

Perumahan Islami Indonesia.(2019). Daftar perumahan islami - perumahan syariah Indonesia. http://www.perumahanislamiindonesia.com/p/daftar-lokasi.html.

Roitman, S. (2010). Gated communities: definitions, causes and consequences. Proceedings of the Institution of Civil Engineers: Urban Design and Planning, I63(I), 31-38.

Tafjel, H., \& Turner, J. C. (1986). The social identity theory of intergroup behavior. Psychology of Intergroup Relations, 7-24.

Taylor, D.M.,\& Moghaddam, F.M.(1994). Theories of intergroup relations. London: Praeger.

Thuillier, G. (2005). Gated communities in the metropolitan area of Buenos Aires, Argentina: A challenge for town planning. Housing Studies, 20(2), 255-27I. 